\title{
Rubella Immunization
}

National Cancer Institute

\section{Source}

National Cancer Institute. Rubella Immunization. NCI Thesaurus. Code C92872.

The administration of a live attenuated viral vaccine to prevent rubella infection. 